\title{
立体画像処理システムの開発とその応用
}

\section{Development and application of a stereoscopic image processing system.}

\author{
森＼cjkstart宣彦, 村井 俊治, 川上 \\ 肇** \\ 瀬川 哲 $* *$ 伊藤 三郎 ${ }^{* * *}$ \\ Nobuhiko MORI, Shunji MURAI, Hajimu KAWAKAMI \\ satoshi SEGAWA, saburo ITO
}

\begin{abstract}
A new type of stereoscopic image display module has been developed, which has an ability to display both stereoscopic images and stereoscopic graphics simultaneously by using liquid crystal shutter glasses. Using this module a low cost PC-based stereoscopic image processing system has been developed. Two application examples using this system have been expressed.One is three dimentional measurement system and the other is GIS.It can be said that this stereoscopic image display module is very useful as man-machine interface of stereoscopic images.
\end{abstract}

\section{1.はじめに}

近年 $\mathrm{CAD}$ 等の分野で三次元グラフィックディスプ レイを用いた，立体図形処理の研究が盛んである。こ れは，液晶シャッタメガネや偏光メガネを用いて，実 用に耐える画質の立体図形が安価な機器で得られる ようになった事や，複雑な立体図形の処理には，図形 を立体視することが非常に有効であるという事が理 解されだしたためと思われる。一方立体画像処理に関 しても, 最近多くの分野で活発な研究開発が行われて いるが, 写真測量の分野では, 古くから写真やフィル ムを用いて画像を光学的に立体視し，等高線等を描く アナログ図化機が用いられてきた。近代では, 光学像 から得られるデー夕をディジタル機器で処理する解 析図化機が主流であるが, 人工衛星等で取得された ディジタル立体画像データをそのままディジタル機 器で処理し, 等高線等を抽出するシステムの研究開発

\footnotetext{
* 東京大学生産技術研究所

**日本電気 $\mathrm{K} . \mathrm{K}$

***日本電気航空宇宙システム $\mathrm{K} . \mathrm{K}$
}

「写真測量とリモートセンシング」Vol. 30,No. 1, 1991
も盛んである。そして，このようなシステムとして， これまでに既にいくつかのシステムが発表されてい るが,これらのシステムにはそれぞれ，2台のディス プレイの画像をハーフミラーで合成しているため, 装 置が大きくなるとか, 価格が数千万円程度と高価にな るとか, 等高線抽出以外の機能があまりないとかいっ た問題点があった。ここで新たに提案する立体画像処 理システムは, 液晶シャッタメガネを用いて, 立体画 像と立体図形を同時に立体視することができる立体 画像表示モジュールを持っており, コンパクトでかつ 価格も数百万円程度と安く, 多くの分野での応用が可 能である。実験システムの開発を終え, いくつかの分 野でその応用に関する検討を行ったので, ここにその 結果を報告する。

\section{2. 液晶シャッタメガネを用いた立体画像 表示モジュールの開発}

立体画像と立体図形を重ね合せてディスプレイに 表示し, 液晶シャッタメガネを用いた方式で, 画像と 図形を同時に立体視する新しい夕イプの立体画像表 示モジュールを開発した。困1はその原理困である。 図 1 において，ステレオぺアを構成する 2 枚の画像 




図 1 立体画像表示モジュールの原理図

(左画像と右画像) は 2 枚のフレームメモリにそれぞ れ記憶される。また，これら 2 枚の画像と重ねて表示 される 2 枚の図形 (左図形と右図形) はパーソナルコ ンピュータ内蔵のビデオメモリ(VRAM)の 2 面に記 憶される。ディスプレイは左画像と左図形を重ねたも の，および右画像と右図形を重ねたものを交互に表示 する。液晶シャッタメガネはディスプレイと同期して 左右の液晶シャッ夕を交互に開くので,このメがネを 掛けてディスプレイを観測すると，左目には左画像の みが，右目には右画像のみが見之，立体画像の立体視 が可能となる。

この図 1 で示した原理に基づき, 実際にハードウェ アを構成したのが図 2 である。図 2 において，一対の 立体画像を記憶するフレームメモリは, パーソナルコ ンピュータ (PC) の拡張スロットに実装される 2 枚の 拡張ボードであり，PCのI/O ポートを介して制御さ れる。このフレームメモリには, 外部から入力される 図形と，内部に記憶した画像を重ね合せて出力する機 能がある。一対の立体図形はPC内蔵のVRAM (Video Random Access Memory) の 2 面に記憶さ れるが，その選択は GDC (Graphic Display Controller)の制御により，バンク切り換えで行われる。液晶 シャッタメガネの制御は, 拡張スロットに実装される 夜晶シャッタメガネコントロールボードにより行わ れる。これら全体の機器の制御は, PCのプログラムメ モリに記憶されたデバイスドライバが行うが，その手 順を以下に示す。

(i) GDC からディスプレイに送られる垂直同期信 号で, デバイスドライバに $60 \mathrm{~Hz}$ の周期で割り込

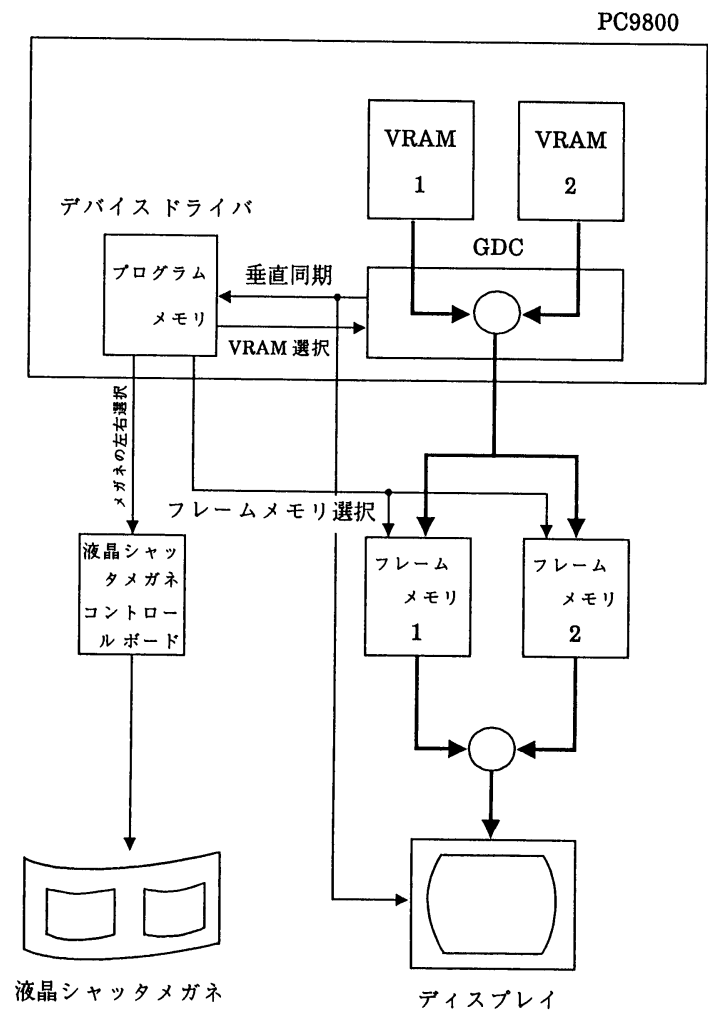

図 2 立体画像表示モジュールのハードウェア構成

みがかけられ，デバイスドライバが起動される。

(ii) デバイスドライバから GDCに「VRAM 選択」 信号が送られる。GDCではこの信号に従って右 又は左の図形をバンク切り換えで選択し, その図 形信号を 2 枚のフレームメモリに送る。

(iii) デバイスドライバから 2 枚のフレームメモリ に「フレームメモリ選択」信号が送られる。フレー ムメモリではこの信号に従って右又は左の画像 を選択し，上記図形信号と重ね合せた画像信号を ディスプレイに送る。

(iv) デバイスドライバから液晶シャッタメガネコ ントロールボードに「メガネの左右選択」信号が 送られる。液晶シャッタメがネコントロールボー ドではこの信号に従って, 右目又は左目用の液晶 シャッタを開けるための一連の信号を発生する。 以上でここで開発した立体画像表示モジュールに ついて詳しく説明したが, 立体図形として三次元マウ ス（マウスの動きとボタン操作で，メスマーク等の マークを立体的に移動させることができるマウス) で 移動するメスマークを用いると，立体視した画像上の 
任意の点の三次元座標を計算機に入力することがで き,またこれらの点から作成したワイヤフレームモデ 儿等の立体図形を，立体画像と重ね合せて出力するこ とができる。この方式では 1 台のディスプレイに 2 枚 の画像を時分割で交互に表示するので，2 台のディス プレイに同時に表示し，それぞれ逆の偏光をかけて ハーフミラーで合成する場合のように, 経年変化等で 周辺で 2 枚の画像に縦視差が生じるとか, 装置が大き く高価になるといったことがなく, 安価でコンパクト な機器で構成することができる。また市販の大画面 ディスプレイに写し出すことも容易にできる。

\section{3．立体画像処理システムの開発}

前記立体画像表示モジュールを用いて，立体画像処 理システムの実験システムを開発した。その構成を図 3 に示す。図 3 において, パーソナルコンピュータ. PC9801は, 全体のコントロールおよび各種演算処理 を行うのに用いる。PCには 2 枚のフレームメモリと 1 枚の液晶シャッ夕メガネコントロールボードが拡 張スロットに実装される。フレームメモリのメモリ容 量は各 $768 \mathrm{~K}$ バイトであり，400×640画素のフルカ ラ一画像 1 枚を記憶することができる。液晶シャッ夕 メガネコントロールボードには, 液晶シャッタメがネ

\section{ディスプレイ}

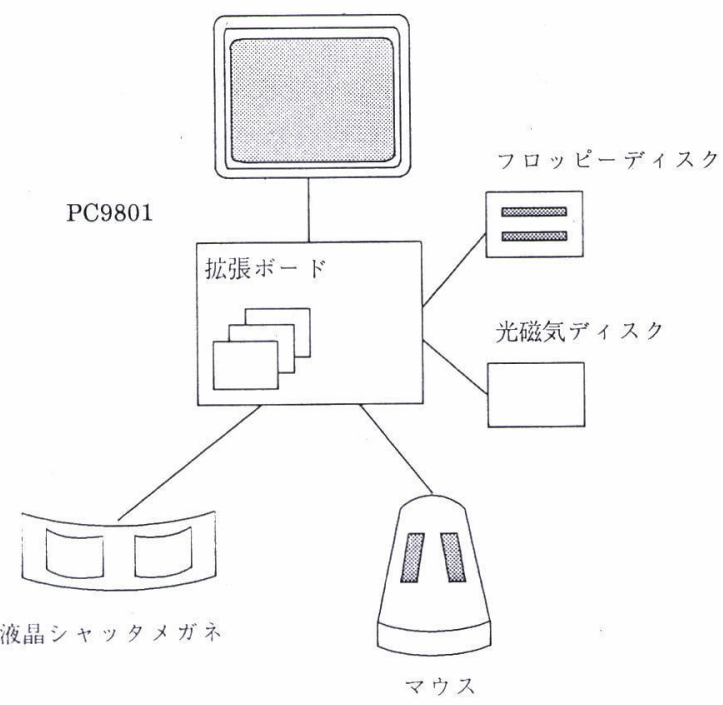

図 3 立体画像処理実験システムの構成
4 台が接続可能であり，4 人まで同時に立体画像を観 測することができる。液晶シャッタメガネ方式の場 合, 液晶シャッタメガネとコントロールボードの間に コードが必要なため, 動き回って観測する作業には不 向きであるが, 大画面ディスプレイが使えるといった 特長がある。ここでは $60 \mathrm{~Hz}$ のディスプレイを用いた ので，市販のものがそのまま使えるが，画面を明るく すると現れるフリッカ(ちらつき)をなくすためには, $120 \mathrm{~Hz}$ のものを用いる必要があり,この場合ディスプ レイは特殊な高価なものとなる。光磁気ディスクは大 容量メモリとして使用するが, 現在約 $600 \mathrm{M}$ バイトの 記憶容量があり，かつ書き換え可能なものが市販され ている。写真 1 はここで開発した立体画像処理実験シ ステムの外観である。

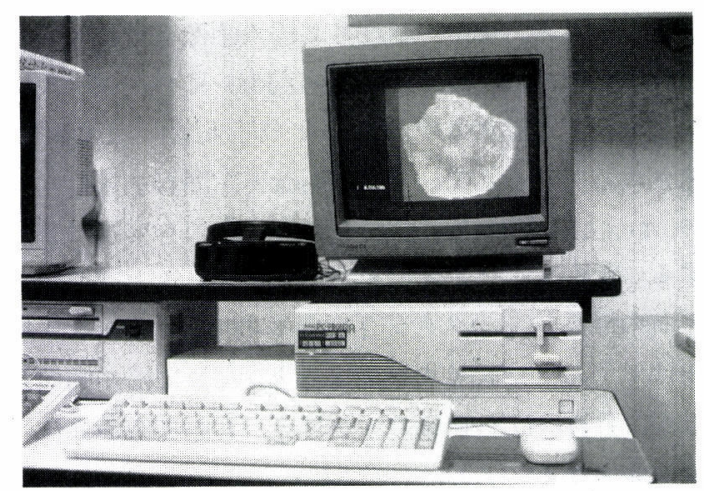

写真 1 立体画像処理実験システムの外観

ここで開発したシステムの最大の特徵は, システム 価格が安価になるように,できるだけ安価な沉用機器 で構成していることである。夜晶シャッタメガネを用 いた方式は，偏光メガネを用いた方式に比べ安価であ る。また中央処理装置としてパーソナルコンピュータ を使用したことは, システム価格を画期的に引き下げ た。パーソナルコンピュータの能力が最近大幅に向上 しているので, パーソナルコンピュータに高速演算プ ロセッサを組み込むと, かなりの処理がこなせるよう になる。

\section{4. 三次元計測への応用}

前記立体画像処理システムの一応用例として,ここ では三次元計測への応用について述べる。写真 2 は三 次元計測の一例を示したものであり, 屋久島の立体画 




写真 2 三次元計測の一例

像と, 三次元空間における位置を指示するメスマーク を表示するための一対の十字のマーク (カーソルマー ク）を左右別々に重ね合せ，2枚の重ね合せ画像を交 互に表示したものである。この表示を液晶シャッタメ ガネを通して観測すると, 立体画像とカーソルマーク が同時に立体視できる。ここで立体画像は 2 枚のフ レームメモリに記憶され, 一対のカーソルマークは立 体図形として，2 面の VRAM に記憶されている。そ してVRAM 内のカーソルマークの位置は, マウスで 自由に移動することができる。一対のカーソルマーク の位置は，立体視するために同一ライン上になければ ならないが，ボタンを押しながらマウスを上下に動か すとその間隔が変り，ボタンを押さずにマウスを平面 内で動かすと, 一対のカーソルマークはその間隔を保 ちながらマウスの動きに追随する。横方向の間隔は立 体視すると高さに相当するのでこれれだけの機能があ れば, カーソルマークの立体像, つまりここではメス マークを三次元空間内で自由に動かすことができる。 写真 2 の左下の 3 つの数字は, メスマークで指示され た位置の三次元座標 $(\mathrm{x}, \mathrm{y}, \mathrm{z})$ であり，それぞれ高さ $(\mathrm{m})$, 左上角からの横方向の距離 $(\mathrm{m})$, 縦方向の距離 (m) を示している。

立体画像が立体視されるためには, 表示した一対の 画像に縦視差がない事が必要であるが, この時 2 枚の 画像におけるステレオ対応点は必ず同一ライン上に ある。従って前述のマウスの機能があれば, 一対の カーソルマークをステレオ対応点の上にU゚ったり重 ねることができる。この動作はとりもなおさず，立体 視した画像上でメスマークを計測点に三次元的に ぴったり合せることであり，このとき計測点の一対の 画像における位置は, 一対のカーソルマークの位置よ
り簡単に求めることができる。そして計測点の三次元 座標は, これらの位置と外部標定要素を用いて, 従来 の写真測量の技術で求めることができる。

このようにこのシステムを用いると, 外部標定要素 が判っている立体画像上の任意の点の三次元座標を 瞬時に求めることができ, 二点間の距離等が簡単に計 算できる。固定した 2 台のビデオカメラの場合は, 外 部標定要素をあらかじめ正確に計測できるので, これ らのカメラで撮影した移動物体の位置, 大きさ, 間隔 等はメスマークで指示するだけで, 瞬時に計算するこ とができ, 今後多方面での利用が期待できる。

このシステムは, 立体画像に関する情報の入力だけ でなく, 計算機内部で作成したワイヤフレームモデル 等の立体図形を画像と重ねて出力し, 目で確か女なが ら各種検討を行う場合にも利用できる。しかしこの場 合，画像から入力した点のみを用いて立体四形を作成 する場合は問題がないものの, そうでない点を用いる 場合は, 立体四形の視点として, 立体画像の外部標定 要素を用いる事が必要である。

\section{GIS への応用}

前記立体画像処理システムの他の応用例として, こ こでは GISへの応用について述べる。GISにおいて地 形情報は重要な意味を持つが，これまで等高線等で表 示していたため, 詳細な表現が困難であった。しかし 立体画像表示モジュールを用いて画像を立体視する と, 地形をありのまま観測できるので詳細な地形情報 が得られ，かつ他の情報を見にくくする事がない。次 にその一例を示す。

写真 3 と写真 4 は, それぞれ伊豆半島の断層四と活 断層困をディジタル化したものであり, 写真 5 はス ペースシャトル搭載大画面カメラ (LFC) で撮影した 伊豆半島の写真をディジタル化し, 正射写真画像に変 換したものである。これらの画像を正確に重なるよう に調整した後, DEM(地上に正方格子を描き，その交 点における標高值を数値で表わした数值高度情報）を 用いてそれぞれのステレオメイトを作る。基線高度比 を一定にすれば，ステレオメイトどうしもまた正確に 重なる。このようにして作成した断層, 活断層, 写真 画像のステレオペアに，それぞれ違った色を与え，原 画像どうし，ステレオメイトどうしを重ね合せて立体 画像表示モジュールで表示すると，3つの画像を同時 


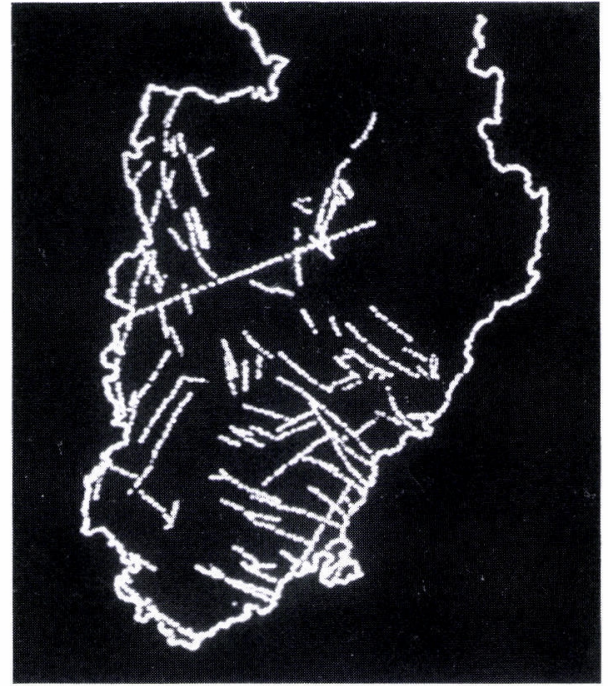

写真 3 伊豆半島の断層図

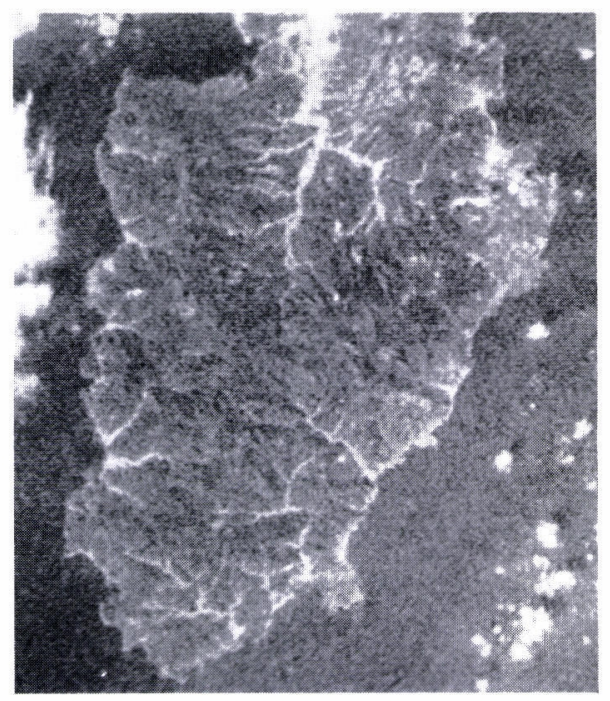

写真 5 伊豆半島の正射写真画像

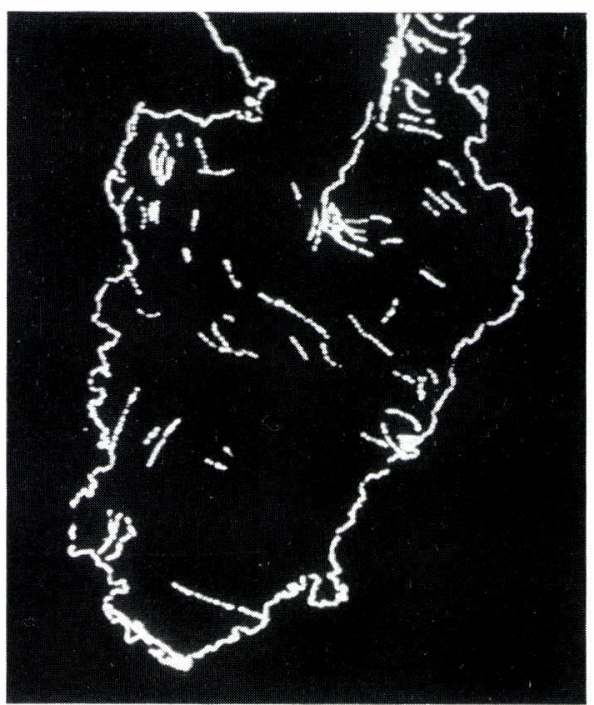

写真 4 伊豆半島の活断層図

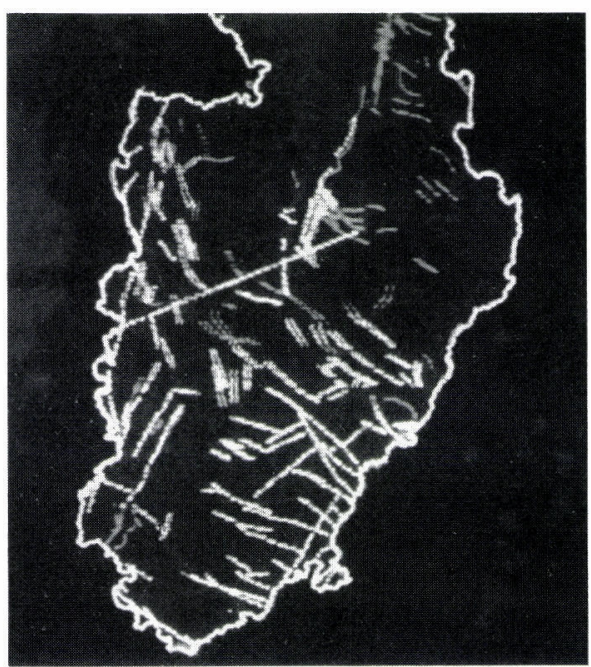

写真 6 重㭘せ画像の交互表示
に立体視することができる。写真 6 は 2 枚の重ね合せ 画像を交互表示しているところである。この画像を液 晶シャッタメガネを通して見ると, 断層と活断層の線 を，立体的な地形の表面に沿って描かれた線として観 測することができる。

このようにこのシステムを用いると, 各種情報を重 ね合せた上立体的に見れるので, 重ね合せ情報の上に さらに詳しい地形情報を加えることができ, より総合 的な判断ができるようになる。またステレオメイト作 成時に，基線高度比を任意に選べるので，それぞれの
場合に最適な基線高度比で立体画像を作成し，効果的 に解析を行うことができる。さらにこの場合も三次元 マウスの使用が可能なので, 重ね合せ立体画像上の任 意の点の位置座標を計算機に入力して計算し，またそ の結果を画像と重ねて立体表示することが可能であ る。

近年パーソナルコンピュータの能力が向上してき ているのでここに示した立体画像処理システムに， 各種入出力機器やデータベースを接続して, ある程度 の能力を持つ GIS を構築することができるが,この立 
体画像表示モジュールを従来の GIS のマンマシン・イ ンターフェースの1つと考之, 部分的に利用してゆく ことも有効であろうと思われる。

\section{6. まと め}

立体画像と立体図形を重ね合せてディスプレイに 表示し, 液晶シャッタメガネを用いた方式で, 画像と 困形を同時に立体視する新しい夕イプの立体画像表 示モジュールを開発した。このモジュールには, 大画 面表示ができるとか, コンパクトで安価であるとか, 複数の人が同時に立体画像を観測できるといった特 長がある。このモジュールをパーソナルコンピュータ システムに組み込み, 大変安価な立体画像処理システ ムを開発した。このシステムは様々な分野での応用が 可能である。三次元計測に応用すると, 立体画像を立 体視しながら, 三次元マウスを用いてメスマークで計 測点を指示することにより, 計測点の座標值や, 計測 点間の距離や, 計測点で囲まれた領域の面積, 体積等 を瞬時に求めることができる。また計算機内部で計測 点から作成したワイヤフレームモデル等の立体図形 を, 立体画像と重ねて出力し, 各種検討を行うことも 可能である。GIS に応用すると, DEM を用いて重ね合 せ画像のステレオメイトを作り，立体視することによ ク, 重ね合せた画像の情報の上にさらに詳細な地形情 報を加えることができ，より総合的な判断ができるよ
うになる。またステレオメイト作成時に基線高度比を 選ぶことにより, それぞれの場合に最適な基線高度比 の立体画像で解析ができるとか, 三次元マウスを用い て, 三次元計測の場合と同様に各種情報の入出力がで きるといった特長もある。このように, この立体画像 処理システムの応用範囲は広く, またこの立体画像表 示モジュールは立体画像に関する情報のマンマシン・ インターフェースとして大変有効であるので, 今後の 各方面での利用が期待できる。

\section{参考 文 献}

1) Mori, Murai, Kawakami, Segawa, Ito ; A Personal Computer System for Processing of Digital Stereoscopic Imagery; The tenth asian conference on remote sensing, Malaysia, Nov.23-29, 1989, pp. Q-6-1 $\sim$ Q-6-6

2) Mori, Murai, Kawakami, Segawa, Ito ; PC-Based Three Dimensional Measurement System Using Liquid Crystal Shutter Glasses; ISPRS Com. IV Tsukuba Sympo., Japan, May 15-18, 1990, pp. 414 421

3 ) 瀬川, 井上, 熊本; 立体視を応用したグラフィックス と 3 次元教示; 2nd Symposium on Human Interface, Tokyo, Oct. 29-30, 1986

4) 大谷仁志; ステレオ画像解析システム; 映像情報, Vol. 21，No. 25, PP.49 54, 1989年12月

5 ）秋山, 小井土; 簡易型解析図化機の開発; 平成元年度 写真測量学会講演会論文集, PP. 123 126, 1989年 5 月

6 ) P. Lohmann, G. Picht, J. Weidenhammer, K. Jacobsen, L. Skog; The design and development of a digital photogrammetric stereo workstation; ISPRS Journal of Photogrammetry and Remote Sensing, 44, PP. 215 224, 1989 